и сами могут выступать в качестве объекта самостоятельного изучения.

Обзор источниковой базы по истории миссионерской деятельности Русской православной церкви второй половины XIX - начала XX в. позволяет сделать вывод о ее многообразии и содержательности. Мы полагаем, что представленные характеристики различных видов архивных источников помогут исследователям адаптироваться в указанном массиве документов. Вместе с тем заметим, что представленная классификация не является окончательной и может быть дополнена.

\section{Список литературы:}

1. Bender C. Practicing religions // The Cambridge companion to religious studies. Cambridge, 2012. P. 273-295.

2. Рижский старообрядческий сборник. Материалы по истории староверия. Вып. II. Рига: Старообрядческое общество Латвии, 2011. 328 с.

3. Таранец С.В. Старообрядчество в Российской империи (конец XVII - начало XX века). Т. 2: Старообрядчество в социокультурном аспекте / под ред. Г.В. Боряка. Институт истории Украины НАН Укра- ины; Музей истории и культуры старообрядчества Украины. Киев, 2013. 688 с.

4. Государственный архив Оренбургской области (ГАОО). Ф. 11. Оп. 11. Д. 1179.

5. ГАОО. Ф. 10. Оп. 8. Д. 97

6. ГАОО. Ф. 173. Оп. 5. Д. 8716.

7. ГАОО. Ф. 175. Оп. 2. Д. 23.

8. ГАОО. Ф. 173. ОП. 5. Д. 9409.

9. Оренбургский государственный архив Челябинской области (ОГАЧО). Ф. И-33. Оп. 1. Д. 3854.

10. ГАОО. Ф. 10. ОП. 8. Д. 154.

11. ГАОО. Ф. 10. ОП. 2. Д. 111.

12. ГАОО. Ф. 173. Оп. 5. Д. 8885 .

13. ГАОО. Ф. 173. ОП. 1. Д. 90.

14. Российский государственный исторический архив (РГИА). Ф. 796. ОП. 151. Д. 1627.

15. РГИА. Ф. 381. ОП. 2. Д. 2516.

16. ГАОО. Ф. 174. ОП. 1. Д. 367.

17. ГАОО. Ф. 10. Оп. 2. Д. 66.

18. ГАОО. Ф. 173. Оп. 4. Д. 6767.

19. ГАОО. Ф. 10. Оп. 2. Д. 112.

20. Записки генерал-майора [Оренб. казачьего войска] Ивана Васильевича Чернова // Тр. Оренб. учен. арх. комис. Оренбург, 1907. Вып. 18. С. 15-224.

\title{
ARCHIVAL SOURCES OF THE RUSSIAN ORTHODOX CHURCH MISSIONARY ACTIVITY HISTORY AMONG THE OLD BELIEVERS OF THE ORENBURG DIOCESE OF THE SECOND HALF OF THE XIX - EARLY XX CENTURIES
}

(C) 2018

Kamzina Alina Dzhanarovna, candidate of historical sciences, associate professor of History of Russia Department Orenburg State Pedagogical University (Orenburg, Russian Federation)

Abstract. The historical period considered in this paper is one of the important periods for the economic, political and spiritual development of the Russian state. The Orenburg Region at this stage was a multi-confessional region, where, despite the leading role of the Russian Orthodox Church, both non-Christian and Christian denominations, including a variety of old believers' consent and sectarianism, were spread. In this regard, the anti-sectarian missionary activity of the official Orthodoxy aimed at both the old believers and sectarians became particularly relevant. Archival documents in the collections of Federal and regional archives form the basis of this problem study. The paper presents an overview of unpublished sources and their source analysis. The author analyses such groups of archival sources as statistical materials, records of management sources, among which a special place is occupied by the Governor's and diocesan reports, documents of personal origin, legislative materials. Among these groups of sources, the most valuable ones are records of civil and spiritual departments. The review allows to conclude about the variety of types of archival documents and their various informative features. The presented classification is not final and can be supplemented.

Keywords: Russian Orthodox church; Orthodox missionary work; old belief; sectarianism; statistical papers; office sources; missionary; Orenburg diocese; diocesan report; Governor's report; Orthodox missionary brotherhood.

УДК 27

DOI 10.24411/2309-4370-2018-14217

Статья поступила в редакцию 05.08.2018

\section{МАТЕРИАЛЫ БЕЛОЭМИГРАНТСКИХ ЦЕРКОВНЫХ ОРГАНИЗАЦИЙ В КИТАЕ КАК ИСТОЧНИК ПО ИСТОРИИ ПРАВОСЛАВНОЙ ЦЕРКВИ}

(C) 2018

Дроботушенко Евгений Викторович, кандидат исторических наук, доцент, декан исторического факультета

Ланцова Юлия Николаевна, кандидат исторических наук, доцент кафедры истории

Забайкальский государственный университет (г. Чита, Российская Федерация)

Аннотация. В статье рассматриваются различные аспекты истории православной церкви в Китае на основе богатейшего источника - материалов белоэмигрантских церковных организаций, собранных в одно объемное дело фонда 9145 «Коллекции отдельных документов различных эмигрантских организаций» Государственного архива Российской Федерации. Данное дело содержит в себе как переписки по отдельным вопросам, так и различного рода листовки, брошюры, газетные статьи, афиши, объявления, отчеты, ведомости, заметки с характеристикой различных аспектов православной истории и охватывает временной период с 1924 
по 1936 гг. Приводятся статьи из газет «Заря», «Гун-бао», духовного журнала «Хлеб Небесный» и др. Анализируется переписка по важнейшим вопросам перехода части китайского духовенства из-под управления Архиерейского Синода Русской Православной Церкви за границей под каноническую юрисдикцию Московского Патриархата и т.д. К сожалению, несмотря на значительный интерес в последнее время к истории российской эмиграции второй четверти XX в. в Китае, а также к истории православия в стране, документы данного дела не получили широкой известности, хотя они дополняют малоизвестные страницы православной истории.

Ключевые слова: православие; церковь; священнослужители; архиепископ; епископ; архиереи; белоэмигрантские церковные организации; эмигранты; Харбин; Шанхай; Русская Духовная Миссия в Китае; Государственный архив Российской Федерации; архивные документы; фонд; опись; дело.

На сегодняшний день история российской эмиграции в Китае второй четверти XX в. является невероятно популярной темой для исследовательского анализа. Существует целый ряд различного рода публикаций как обобщающего характера, так и специальных [1-14].

Отметим, что не осталась в стороне от изучения и история православной церкви в Китае в рассматриваемое время. Общую ее характеристику и описание отдельных аспектов можно найти у таких авторов, как С.Н. Баконина, В.Г. Дацышен, Иоанн Ду, Н.М. Векшина, В.С. Печерица, Дионисий Поздняев, В.С. Русак, И.Г. Сиренко, Ю.С. Федорова, Д.В. Хмыров и др. [15-28].

В то же время нельзя сказать, что существующие публикации воссоздают историю православных церковных эмигрантских организаций в Китае в полной мере. Она требует определенного дополнения, что предопределяет серьезную работу с источниками. Часть из них, отдельные издания периодической печати, мемуары, некоторые архивные документы получили относительно широкую известность. Однако имеются и малоизвестные или вообще неизвестные широкому кругу. К таким мы относим, в частности, «Материалы белоэмигрантских церковных организаций в Китае». Дисперсно они представлены в различных архивных делах, к примеру, Государственного архива Российской Федерации. В то же время фонды данного архива содержат отдельное дело с соответствующим названием, которое хронологически содержит в себе документы с 1924 по 1936 гг., т.е. времени своеобразного «расцвета» российской эмиграции в Китае. Данное дело относится к первой описи интереснейшего фонда 9145 «Коллекции отдельных документов различных эмигрантских организаций» [29].

На документах названного дела, как и на многих иных, относящихся к истории российской миграции в Китае, стоит печать Русского заграничного исторического архива в Праге. Как известно, в 1945 г. его рукописная часть была передана Академии наук СССР. В настоящее время документы хранятся в Государственном архиве Российской Федерации.

Особенность материалов в том, что они не систематизированы, это просто подборка различных писем, вырезок и т.д., при этом расположены они не в хронологическом порядке. К примеру, первым идет воззвание от 1936 г, далее вырезки из газет от 1928 г. и т.д. Часть материалов без указания даты.

Все материалы можно условно разделить на группы:

- газетные публикации, представленные в значительной степени в виде вырезок;

- обращения правящих архиереев к пастве;

- переписки и отдельные письма;

- отчеты и заметки с характеристикой какоголибо аспекта православной истории;
- афишы и объявления;

- брошюры;

- извещения, тексты речей, озвученных прихожанами, ведомости.

Интереснейшей в характеризуемом деле представляется подборка вырезок из эмигрантских газет, содержащая в себе сведения по православной церкви в Китае. Они также не систематизированы, разбросаны по всему делу.

В рассматриваемом деле содержится подборка газетных заметок, собранная представителем российской эмиграции. Так, в ней имеется заметка, которая опубликована в номере 129 газеты «Заря» от 14 мая 1928 г. В ней Архиепископ Харбинский и Маньчжурский Мефодий заявил, что церковь не должна участвовать в деятельности политических организаций. Это стало ответом на замечание генерала Д.Л. Хорвата о том, что представители православной церкви должны следовать его указаниям как Главы русской эмиграции на Дальнем Востоке. Заверения в своей поддержке, как он сам говорил, ему высказали Архиепископ Пекинский, Глава Духовной Миссии в Китае Иннокентий (Фигуровский), Архиепископ Харбинский и Маньчжурский Мефодий (Герасимов), Епископ Шанхайский Симон (Виноградов), Епископ Маньчжурский Мелетий (Заборовский), Харбинский православный епархиальный совет, Харбинский старообрядческий епархиальный Совет, православная община Ломакина $[29$, л. 3]. Сложно сказать, насколько правдиво сообщение Д.Л. Хорвата о том, что в своей поддержке его заверили все православные архиереи Китая. Вероятно, не зря появилось заявление Архиепископа Мефодия (Герасимова) о невозможности участия церкви в политических организациях, коей он считал эмигрантские структуры в Китае.

Через год в газете «Фашист» появляется заметка о создании в Харбине Совета (суть его деятельности не ясна), Почетным Председателем которого стал Архиепископ Харбинский и Маньчжоу-Ди-го Мефодий (Герасимов) [29, л. 3]. Интересна данная заметка несколькими обстоятельствами. Во-первых, марионеточное государство Маньчжоу-го (Маньчжоу-Диго, Даманьчжоу-диго) существовало с 1931 г., а номер газеты «Фашист» датирован 1 августа 1929 г. Во-вторых, встреченное именование Мефодия (Герасимова) Архиепископом Маньчжоу-Ди-го, является, пожалуй, чуть ли не единственным. Его так не именуют ни в имеющихся публикациях, ни в каких-либо иных архивных документах. В-третьих, как известно, газета «Фашист» издавалась в США, начиная с 1933 г., в Харбине же русскими фашистами издавалась газета «Наш Путь», выходившая также с 1933 г. И, в-четвертых, если отмеченное в заметке является правдой (с учетом путаницы с названием газеты и, возможно, с годом появления заметки), то Мефодий 
поддерживал марионеточное правительство Маньчжоу-Ди-го и, соответственно, участвовал в политической деятельности. С другой стороны, следует сказать, что спорность информации в приведенном документе позволяет поставить под сомнение указанное. Очевидно, что здесь требуется серьезная дальнейшая работа с источниками для выяснения истинной картины.

Не менее интересный материал, чем газетные публикации, дают различные воззвания и обращения к верующим со стороны правящих архиереев.

Объемное по содержанию воззвание касается возведения в Харбине «величественного храма в центре нового города». В нем подробно расписывается получение участка от китайских властей, закрепление его за Свято-Покровским Украинским приходом. Это участок старого кладбища на углу Большого проспекта и Мукденской улицы. Создан Строительный комитет во главе с настоятелем Украинского прихода протоиреем Николаем Труфановым при деятельном участии почетных членов, митрофорного протоиерея Леонтия Пекарского (он основоположник украинского прихода) и благочинного протоиерея Михаила Рогожина. Проект храма сделан как копия иркутского собора в уменьшенном виде инженером Ю.П. Ждановым и техником С.С. Бруевичем [29, л. 4].

К 1936 г. относится Воззвание Епископа Виктора (Святина) и Главы русской эмиграции на Дальнем Востоке генерала Д.Л. Хорвата «...ко всем добрым людям, сочувствую открытию санатория для туберкулёза больных в горах Ляошань, вблизи Циндао». Данный санаторий был открыт под покровительством Русской Духовной Миссии в Китае. Документ особо показателен, так как он характеризует благотворительно-лечебную деятельность православной церкви в достаточно сложные в финансовом плане для нее годы. Для организации санатория при Миссии был учрежден за некоторое время до того специальный Комитет под председательством Епископа Синьцзянского, второго викария Русской Духовной Миссии в Китае Ювеналия (Килина). Все пожертвования на санаторий поступали в распоряжение названного комитета, а расходы освещались в ежемесячных отчетах. Санаторий получил наименование Свято-Пантелеймоновского [29, л. 2].

Охарактеризованное обращение представляет интерес прежде всего тем, что источники и имеющиеся публикации о названном санатории практически не говорят, в самой малой степени характеризуют такой вид деятельности православной церкви в Китае, как организация и содержание санаториев.

Материалы содержат и иные обращения и воззвания. К примеру, воззвание от марта/апреля 1928 г. настоятеля Казанско-Богородицкого монастыря в Харбине архимандрита Ювеналия (Килина), будущего епископа Синьцзянского, второго викария Русской Духовной Миссии в Китае, а затем Епископа Шанхайского. В нем он просит паству о помощи в организации дел православной церкви в Харбине [29, л. 24].

Важнейшие аспекты существования православия в стране находят освещение в ряде писем и переписках, также представленных в рассматриваемых материалах. Значительная часть из них посвящена вопросам перехода части православного китайского духо- венства и верующих из-под управления Архиерейского Синода Русской Православной Церкви за границей под каноническую юрисдикцию Московского Патриархата и возникшей в связи с этим напряженностью.

В 1930 г. появляется открытое письмо Митрополита Иннокентия (Фигуровского), в котором описывалась статья в газете «Гун-бао», согласно тексту которой часть священнослужителей «перешла к Митрополиту Сергию», присоединившись к «полуобновленцам» [29, л. 223].

Примерно к тому же времени относится появление письма Председателя церковно-приходского совета Свято-Николаевского военно-морского прихода в Шанхае генерал-лейтенанта Л.Г. Глебова на имя благочинного православных церквей Шанхая архимандрита Макария (от 1932 г.), в котором он отмечает, что не может молчать, когда в храме за Божественной литургией постоянно говорят о постановлениях Собора архиереев Русской Православной Церкви за границей. Судя по всему, он являлся сторонником Московской Патриархии. В письме отмечал, что «смуты» уже и так посеяно много, и просил пресечь происходившее [29, л. 225].

Один из документов представляет собой обращение группы православных христиан по поводу того, что в Тяньцзине священник Сергей Чан «предал себя и свою паству красной Москве» с просьбой к верующим «опомниться» [29, л. 38].

Названные документы говорят о том, что в рассматриваемые годы в Китае православную церковь раздирали противоречия, связанные с тем, оставаться ли под каноническим управлением Архиерейского Синода Русской Православной Церкви за границей или же перейти под управление Московской Патриархии. Как видим, данные противоречия затронули разные города, в которых существовали относительно большие православные общины. В ряде случаев противоречия переходили в конфликты.

Отдельными документами в рассматриваемых материалах представлены отчеты о деятельности различных структур православной церкви. Примером такого отчета может являться годовой отчет Русского Православного Свято-Богоявленского Братства в Шанхае за период с 1 мая 1924 по 1 мая 1923 гг. Данный отчет издан в виде небольшой брошюры. В нем дается характеристика деятельности братства, отмечается, что за первые годы существования (с 22 февраля 1923 г.) открыты амбулатория, коммерческое училище, постоянно проводятся новогодние праздники для детей русских эмигрантов в Шанхае, раздача одежды и обуви малоимущим [29, л. 261a-286].

Иным примером отчета может быть назван «Отчет комиссии по сооружению православной храма в Шанхае» от 1928-1930 гг. [29, л. 241a-255].

Интересными, а самое главное, достаточно информативными являются различные заметки, в которых характеризуется тот или иной аспект истории православия в Китае. Здесь примером могут являться заметки по Православному Китайскому Миссионерскому Братству во имя Святого Иннокентия, первого епископа Иркутского в Тяньцзине, в которых характеризуется история создания братства, его деятельности и проблемы существования, главным образом финансовые [29, л. 24]. 
Богатейшим иллюстративным материалом деятельности православной церкви в Китае являются различные листовки и афиши. В них, как правило, прописывается проведение разного рода мероприятий. Одним из ярчайших примеров является программа торжественного заседания, посвященного памяти умершего митрополита Мефодия (Герасимова). В программу вошли: «слово Высокопреосвященнейшего Мелетия (Заборовского), протоиерея М. Филологова, К.М. Александрова, Е.Н. Сумарокова; Концерт Й. Гайдна "Семь слов Спасителя на кресте"» [29, л. 220].

Иным интересным примером документов являются всевозможные брошюры. Достаточно много их представлено в виде богословских текстов на двух листах, отпечатанных на станции Маньчжурия в типографии В.В. Середина. Это издание православной миссии в пользу Маньчжурского международного комитета попечения и помощи сиротам и нуждающимся по цене в одну копейку [29, л. 57].

Материалы содержат также подобные издания в виде приложения к духовному журналу «Хлеб Небесный», который издавался с января 1926 г. в Харбине. Приложение называлось «Крупицы хлеба небесного» [29, л. 63-74].

Достаточно яркой выглядит брошюра на глянцевой бумаге с фотографиями от 8 мая 1932 г. «Коммерческое училище Русского Православного Братства в Шанхае, издание к закладке собственного здания» [29, л. 237-239].

Относительно большой объем документов - это различные извещения, небольшие по объему, напечатанные речи прихожан, ведомости либо просто заметки. Примеров таких документов достаточно много. К примеру, извещение об открытии при Казанском монастыре амбулатории и аптеки в декабре 1930 г. или слово от прихожан у гроба митрополита Мефодия (Герасимова) 31 марта 1931 г. [29, л. 118, 194].

В материалах представлены ведомости императорского училища Русского Православного Братства, заметки о закупке печатных станков для упрощения издания газеты «Хлеб Небесный» и др. [29, л. 8, 29].

Выше приведены самые разные по характеру документы, входящие в состав Материалов белоэмигрантских церковных организаций в Китае, выделены группы, к которым их можно отнести, с приведением отдельных примеров. При этом следует сказать, что сами материалы очень объемны и могут являться объектом большого самостоятельного исследования.

Можно с уверенностью констатировать, что данные материалы, собранные в одно объемное дело фондов Государственного архива Российской Федерации, представляют собой ценнейший источник как по истории российской эмиграции, так и по истории православной церкви. Документы, его составляющие, дополняют имеющиеся сведения и позволяют заполнить некоторые, пока еще чистые, страницы истории православия. В то же время представляется, что названным делом архивные фонды по проблематике исследования не ограничиваются. При дальнейшей кропотливой работе могут быть выявлены и иные дела по истории эмигрантских церковных организаций в Китае. Вкупе с документами иных дел и иных фондов появляется возможность формирования более полного представления о существовании православной церкви в стране.

\section{Список литературы:}

1. Аблажей Н.Н. С востока на восток: российская эмиграция в Китае. Новосибирск: Издательство СО PAH, 2007. $300 \mathrm{c}$.

2. Аблова Н.Е. КВЖД и российская эмиграция в Китае. М.: ИД «Русская панорама», 2004. 432 с.

3. Адрианов И.К. Дальневосточная казачья эмиграция в Маньчжурии в условиях японской оккупации 30-х гг. XX в. [Электронный ресурс] // http://istkonkurs.ru/raboty/2012/655-30-хx.

4. Аргудяева Ю.В. Русское население Трехречья. [Электронный ресурс] // Города и остроги земли сибирской. - http://ostrog.ucoz.ru/publ/a/argudjaeva_ju_v/ russkoe_naselenie_v_trekhreche/143-1-0-213.

5. Аурилене Е.Е. Российская эмиграция в Китае: 1920-1950: дис. ... д-ра истор. наук: 07.00.02. Хабаровск, 2004. $376 \mathrm{c}$.

6. Аурилене Е.Е. Российская диаспора в Китае: Маньчжурия. Северный Китай. Шанхай (1920-50-е гг.). Хабаровск: Хабаровский пограничный институт Федеральной службы безопасности Российской Федерации, 2003. 191 с.

7. Балмасов С.С. Белоэмигранты на военной службе в Китае. М.: Центрполиграф, 2007. 557 с.

8. Забияко А.П. Русские в Трехречье: исторический очерк // Emigrantologia Słowian. 2016. Vol. 2 S. 5-17.

9. Казачья эмиграция в Маньчжурии 1920-1945 // Донские казаки в борьбе с большевиками [Электронный pecypc]. - http://elan-kazak.org/forum/viewtopic.php?t=926.

10. Казачья эмиграция в Маньчжурии 1920-1945. Союз казаков на Дальнем Востоке [Электронный ресурс] // Рустрана. http://рустрана.pф/18478/kazachyaemigratsiya-v-manchzhurii-1920-1945-gg.-soyuz-kazakovna-dalnem-vostoke.

11. Тарасов А.П. Русские в Барге: история и поиск национальной идентичности в приграничном Китае // Традиционная культура. 2014. № 4 (56). С. 3-14.

12. Чапыгин И.В. Казачья эмиграция в русской диаспоре Северо-Восточного Китая (1920-1945 гг.): дис. ... канд. ист. наук: 07.00.03. Иркутск, 2006. 187 с.

13. Чапыгин И.В. Казачья эмиграция на территории Маньчжурии (1920-1945 гг.) // История Белой Сибири. Кемерово: ИНТ, 2009. С. 275-281.

14. Чапыгин И.В. Казачья эмиграция в Китае. Иркутск: Изд-во ИГУ, 2015. 171 с.

15. Баконина С.Н. Русская Православная Церковь в Маньчжурии и местные китайские власти (страницы биографии епископа Камчатского Нестора (Анисимова), 1923-1928 гг.) // Общество и государство в Китае: XXXIX науч. конф. Ученые записки Отдела Китая ИВ РАН. М.: Восточная литература, 2009. Вып. 1. С. 346-355.

16. Баконина С.Н. Церковная жизнь русской эмиграции на Дальнем Востоке в 1920-1931 гг. М.: Православный Свято-Тихоновский гуманитарный университет, 2014. 389 с.

17. Векшина Н.М. Православие в Китае [Электронный ресурс] // Познание запредельного: современное востоковедение и духовные традиции Востока. - https://torchinov.com/торчиновские-чтения/первыеторчиновские-чтения/н-м-векшина-православие-в-китае.

18. Дацышен В.Г. История Российской духовной миссии в Китае. Гонконг: Православное Братство святых Первоверховных апостолов Петра и Павла, 2010. 448 c. 
19. Дацышен В.Г. Китайская православная церковь накануне и во время Второй мировой войны // Государство, общество, церковь в истории России $\mathrm{XX}$ века: матер. XV междунар. науч. конф. Иваново, 23-24 марта 2016 г. В 2 ч. Ч. 1. Иваново: Изд-во «Ивановский государственный университет», 2016. C. $124-130$.

20. Дионисий (Поздняев), священник. Церковь в Китае: на пути к автономии // Альфа и Омега. 1997. № 3 (14).

21. Ду Иоанн. Распространение Русской Православной Церкви в Тяньцзине и его окрестностях // Китайский Благовестник. 1999. № 2.

22. Печерица В.Ф., Сиренко И.Г. Русская православная эмиграция в Китае в 20 -е - 40-е гг. XX в. // Религиоведение. 2007. № 2. С. 43-48.

23. Поздняев Дионисий, священник. Русская Православная Церковь на Дальнем Востоке в 30-40-е гг. $\mathrm{XX}$ века [Электронный ресурс] // Самый Восточный. Информационно-просветительский портал Хабаровской епархии. - http://pravostok.ru/blog/rysskaya- pravoslavnaya-cerkov-na-dalnem-vostoke-v-30-40-e-godixx-veka.

24. Православие в Китае / под ред. М.Л. Титаренко. М.: Отдел внешних церковных связей Московского Патриархата, 2010. 251 с.

25. Православие в Китае: сбор. матер. выставки / сост. В.В. Селивановский. Благовещенск: Изд-во «Амурская ярмарка», 2013. 68 с.

26. Русак В.С. Православие в Китае в XX веке [Электронный pecypc] // takua.ru. - http://takya.ru/ nuda/pravoslavie-v-kitae-v-hh-veke/main.html.

27. Федорова Ю.С. Русская православная церковь в Северо-восточном Китае. 20-30 гг. ХХ в. // Россия и АТР. 2004. № 3. С. 102-113.

28. Хмыров Д.В. Русская церковная эмиграция в Китае в историко-политическом контексте: от эры милитаристов до японо-китайской войны (19171937) // Христианские чтения. 2013. № 1. С. 155-166.

29. ГАРФ (Государственный архив Российской Федерации). Ф. 9145. Оп. 1. Д. 234.

\title{
MATERIALS OF WHITE EMIGRANT CHURCH ORGANIZATIONS IN CHINA AS A SOURCE ON THE ORTHODOX CHURCH HISTORY
}

(C) 2018

Drobotushenko Evgeny Viktorovich, candidate of historical sciences, dean of History Faculty

Lantsova Yuliya Nikolaevna, candidate of historical sciences, associate professor of History Department Transbaikal State University (Chita, Russian Federation)

Abstract. The paper deals with various aspects of the Orthodox Church history in China on the basis of a rich source - materials of white emigrant Church organizations collected in one large file of the Fund 9145 «Collections of individual documents of various emigrant organizations» of the state archive of the Russian Federation. This file contains correspondence on specific issues as well as various flyers, brochures, newspaper articles, posters, announcements, reports, statements, notes with the characteristics of various aspects of Orthodox history and covers the time period from 1924 to 1936. Articles from the Newspapers «Zarya», «Gong Bao» as well as a spiritual magazine «Bread heavenly», etc. deal with the key issues of the transition of the Chinese clergy under the control of the Synod of bishops of the Russian Orthodox Church outside of Russia under the canonical jurisdiction of the Moscow Patriarchate, etc. Unfortunately, despite the considerable interest in the history of Russian emigration in the second quarter of the $20^{\text {th }}$ century in China, as well as in the history of Orthodoxy in the country, the documents of this file have not been widely known, although they are the supplement of the little-known pages of Orthodox history.

Keywords: Orthodoxy; Church; clergymen; Archbishop; Bishop; Bishops; White emigrant Church organizations; emigrants; Harbin; Shanghai; Russian Spiritual Mission in China; State archive of Russian Federation; archival documents; fund; inventory; business.

УДК 94

DOI 10.24411/2309-4370-2018-14218

Статья поступила в редакцию 14.08.2018

\section{МАТЕРИАЛЬНО-ТЕХНИЧЕСКАЯ БАЗА ФИНАНСОВЫХ ОРГАНОВ ЧЕЛЯБИНСКОЙ ОБЛАСТИ В ГОДЫ ВЕЛИКОЙ ОТЕЧЕСТВЕННОЙ ВОЙНЫ}

(C) 2018

\author{
Ивлев Никита Николаевич, кандидат исторических наук, \\ доцент кафедры социально-гуманитарных дисциплин \\ Южн-Уральский государственный институт искусств им. П.И. Чайковского \\ (2. Челябинск, Российская Федерация)
}

Аннотация. В статье рассмотрено материально-техническое положение финансовых органов на территории Челябинской области, сложившееся в 1941-1945 гг. Приведена структура областных финансовых учреждений, в которую входили финансовые отделы (областной финансовый отдел, городские, районные финансовые отделы), сберегательные кассы и банки долгосрочного кредитования. Изучена динамика изменений материально-технического обеспечения областной финансовой системы в годы войны. Анализ архивных источников наглядно свидетельствует о том, что в первые годы войны материально-техническое обеспечение областной системы финансовых органов находилось в критическом состоянии: не хватало служебных помещений, транспорта, счетных и пишущих машинок и другого необходимого для работы оборудования. Но с началом коренного перелома на фронтах ситуация постепенно начала улучшаться. Увеличивается денежное 